\title{
Metabolic rhythms in adolescents with diabetes during treatment with porcine or human insulin
}

\author{
M D HOCKING, J CRASE, P H W RAYNER, AND M NATTRASS \\ Children's Hospital, Ladywood, and Diabetic Clinic, General Hospital, Birmingham
}

SUMMARY Metabolic rhythms were studied over 24 hours in eight adolescent diabetic patients during treatment with porcine insulin and after transfer to human insulin.

Despite an increase in dose with human insulin no significant changes were found in fasting blood glucose, $24 \mathrm{~h}$ mean blood glucose, or glycosylated haemoglobin concentrations.

Significantly higher $24 \mathrm{~h}$ mean blood lactate concentrations and lower total ketone bodies and glycerol concentrations were observed during treatment with human insulin. These findings are consistent with the increase in insulin dose and do not necessarily imply different metabolic responses to species differences in insulin.

Human insulin prepared by bacterial synthesis $(\mathrm{crb})^{1}$ or by modification of porcine insulin $(\mathrm{emp})^{2}$ is widely available for clinical use. Although there is little evidence that human insulin confers any advantage in the treatment of insulin dependent diabetes mellitus, it has been advocated as the treatment of choice for newly diagnosed diabetic children, ${ }^{3}$ although others suggest that there does not seem to be a case for routine transfer of diabetic children from highly purified porcine to human insulin. ${ }^{4}$

While no differences have been observed in metabolic responses to intravenous porcine or human insulin, ${ }^{5}$ previous reports indicate minor differences in onset, peak, and duration of action of intermediate and long acting preparations of porcine and human insulins. ${ }^{6}$

Clearly, it is important to document changes in glucose and other intermediary metabolites that may occur on changing patients from treatment with porcine insulin to treatment with human insulin.

\section{Methods}

Patients. Eight insulin dependent adolescent patients (five boys) were studied. Their ages ranged from 11.1 to 15.5 years (mean 13.5 years), and duration of diabetes was from $2 \cdot 1$ to $6 \cdot 0$ years (mean $4 \cdot 2$ years). Patients were not included if, on clinical or biochemical evidence, they were in the honeymoon period of diabetes or in partial remission. ${ }^{7}$

Seven patients were treated with twice daily short and intermediate acting porcine insulins (Actrapid and Monotard, Novo Laboratories, Basingstoke, Hampshire, or Velosulin and Insulatard, Nordisk Ltd, Epsom, Surrey), and one patient was treated with Semitard and Monotard (Novo Laboratories) in the morning only. The study was approved by the ethical committee of the Central Birmingham Health Authority.

Protocol. A 24 hour metabolic profile was performed at the start of the study after recruitment. The patients were immediately changed to twice daily soluble and isophane human insulin (crb) (Humulin, Eli Lilly, Basingstoke, Hampshire) in similar proportions to their previous insulin. Treatment with human insulins continued for two months, during which time adjustments to dosage were made by a paediatrician on the basis of home blood glucose monitoring results.

Patients were admitted to hospital the evening before the study. At $0730 \mathrm{~h}$ a teflon cannula $(22$ gauge Abbocath-T, Abbot Ireland Ltd, Sligo, Republic of Ireland) was inserted into an antecubital vein. Between samples the cannula was kept patent by flushing with saline $(154 \mathrm{mmol} / \mathrm{l})$. A fasting sample was taken at $0800 \mathrm{~h}$, after which insulin was given. Blood samples were taken hourly until $2200 \mathrm{~h}$ then two hourly to $0600 \mathrm{~h}$. Breakfast was eaten at $0830 \mathrm{~h}$, lunch at $1215 \mathrm{~h}$, and dinner at $1815 \mathrm{~h}$, with snacks at $1030 \mathrm{~h}, 1530 \mathrm{~h}$, and $2130 \mathrm{~h}$. Evening insulin was given at $1745 \mathrm{~h}$. The carbohydrate content of the diet and individual meals was that prescribed for regular consumption at home and was the same for the two studies. 
Patients were encouraged to be ambulant between blood samples, being free to leave the ward and move between floors of the hospital.

Blood $(6 \mathrm{ml})$ was withdrawn after discarding $2 \mathrm{ml}$ from the cannula. Whole blood (1-2 $\mathrm{ml}$ ) was mixed with ice cold $5 \%(\mathrm{v} / \mathrm{v})$ perchloric acid and refrigerated immediately. The remainder was placed in a plastic tube and after clotting serum was separated and stored at $-20^{\circ} \mathrm{C}$ for subsequent measurement of $C$ peptide and growth hormone concentrations. Glucose, lactate, pyruvate, 3-hydroxybutyrate, glycerol, and alanine concentrations were measured in the perchloric acid extract by continuous flow enzymatic fluorimetric techniques. ${ }^{8}$ Acetoacetate was measured within 36 hours in the perchloric acid extract by a spectrophotometric method. ${ }^{9}$ Serum growth hormone concentration was measured by a double antibody radioimmunoassay. ${ }^{10}$ Serum C peptide concentration was measured by a single antibody method using antibody M1230 from a commercially available kit (Novo Laboratories, Copenhagen, Denmark) after precipitation of proinsulin/insulin antibody complexes using polyethylene glycol. ${ }^{11}$ Total glycosylated haemoglobin concentration was measured in the fasting blood sample by electroendosmosis (Corning Limited, Halstead, Essex). The normal range in our laboratory is $5 \cdot 8 \%-8 \cdot 5 \%$.

Student's $t$ test for paired samples was used to compare glycosylated haemoglobin concentration, insulin dose, and fasting concentrations of metabolites between studies. Metabolic data were analysed using two way analysis of variance ${ }^{12}$ with data classified by study and time. For the missing values during the night the value of the previous hour was repeated. For numerical comparison of the $24 \mathrm{~h}$ rhythm data in the studies an average of the $24 \mathrm{~h}$ mean value was calculated. Total ketone bodies (the sum of 3-hydroxybutyrate and acetoacetate) was log transformed before analysis as the data did not fit a Gaussian distribution. ${ }^{13}$

\section{Results}

Insulin dose increased in all patients from mean $(\mathrm{SEM}) 1 \cdot 0(0 \cdot 1) \mathrm{U} / \mathrm{kg}$ during treatment with porcine insulin to $1.2(0 \cdot 1) \mathrm{U} / \mathrm{kg}(\mathrm{p}<0 \cdot 01)$, but there were no significant differences in the proportion of insulin given in the morning $(69 \% v 63 \%)$ nor in the proportion given as quick acting insulin $(39 \% v$ $40 \%$ ). Despite the increase in insulin dosage total glycosylated haemoglobin concentration did not change significantly $(13 \cdot 1(1 \cdot 1) \% v 12 \cdot 4(0 \cdot 7) \%)$.

Fasting blood glucose concentration was higher during treatment with human insulin, although this did not reach significance (Table 1). Average $24 \mathrm{~h}$ mean blood glucose concentration was similar during both studies (Table $2 ; \mathrm{F}=0 \cdot 24 ; \mathrm{NS}$ ). Blood glucose control was poor during both studies (Fig. 1) with higher mean concentrations during the day with porcine insulin and higher mean concentrations during the night with human insulin.

Fasting blood lactate concentration was not different between studies (Table 1). After breakfast and morning human insulin there was a more pronounced rise in blood lactate concentration

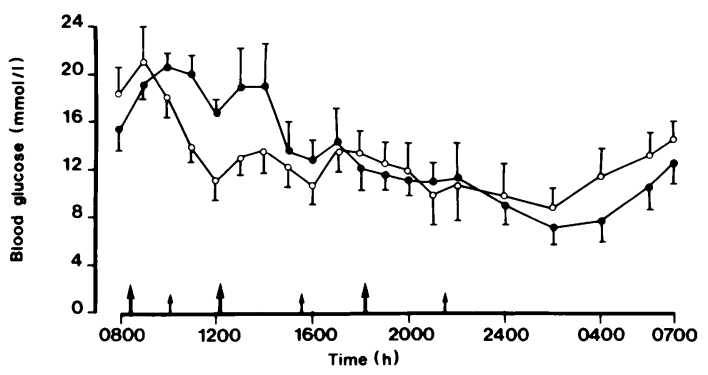

Fig. 1 Blood glucose concentration (mean (SEM)) over 24 hours in eight adolescent diabetic patients during treatment with porcine $(-)$ ) or human $(\mathrm{O}-\mathrm{O})$ insulin. The large arrows indicate meals and the small arrows snacks.

Table 1 Fasting concentrations (mean (SEM)) of blood metabolites (mmolll) and ratios in eight adolescent diabetic patients during treatment with porcine or human insulin. Statistical analysis was by Student's test for paired samples

\begin{tabular}{|c|c|c|c|c|c|c|c|c|c|c|}
\hline Treatment & Glucose & Lactate & Pyruvate & $\begin{array}{l}\text { Lactate: } \\
\text { pyruvate }\end{array}$ & $\begin{array}{l}\text { 3-Hydroxy- } \\
\text { butyrate }\end{array}$ & $\begin{array}{l}\text { Aceto- } \\
\text { acetate }\end{array}$ & $\begin{array}{l}\text { Total } \\
\text { ketone } \\
\text { bodies }\end{array}$ & $\begin{array}{l}3-O H B: \\
A C A C\end{array}$ & Glycerol & Alanine \\
\hline Human insulin & $\begin{array}{l}18 \cdot 4 \\
(2 \cdot())\end{array}$ & $\begin{array}{c}0.84 \\
(0.53)\end{array}$ & $\begin{array}{c}0 \cdot(07 \\
(0 \cdot 01)\end{array}$ & $\begin{array}{l}12 \cdot 4 \\
(() \cdot 4)\end{array}$ & $\begin{array}{c}0 \cdot 80 \\
(0 \cdot 22)\end{array}$ & $\begin{array}{c}0 \cdot 37 \\
(0 \cdot 08)\end{array}$ & $\begin{array}{c}1 \cdot 18 \\
(0 \cdot 30)\end{array}$ & $\begin{array}{c}2 \cdot 0 \\
(0 \cdot 2)\end{array}$ & $\begin{array}{c}0 \cdot 12 \\
(0 \cdot 01)\end{array}$ & $\begin{array}{c}0 \cdot 20 \\
(0 \cdot 01)\end{array}$ \\
\hline p Value & NS & NS & $<0.05$ & $<0.05$ & NS & NS & NS & NS & NS & NS \\
\hline
\end{tabular}

NS=not significant; 3-0HB: $\mathrm{AcAc}=3$-hydroxybutyrate:acetoacetate.

Conversion: SI to traditional units-Glucose: $1 \mathrm{mmol} / \mathrm{l} \approx 18 \mathrm{mg} / 100 \mathrm{ml}$; lactate $1 \mathrm{mmol} / \mathrm{m} \approx 9 \mathrm{mg} / 1(0) \mathrm{ml}$; pyruvate $1 \mathrm{mmol} / 1 \approx 8 \cdot 8 \mathrm{mg} / 1(0) \mathrm{ml}$; acetoacetate $1 \mathrm{mmol} / \mathrm{l} \approx 10 \cdot 2 \mathrm{mg} / 100 \mathrm{ml}$; glycerol $1 \mathrm{mmol} / \mathrm{l} \approx 9.2 \mathrm{mg} / 1(\%) \mathrm{ml}$. 
Table 2 Average 24h mean (SEM) of blood metabolites (mmolll) and ratios in eight adolescent diabetic patients during treatment with porcine or human insulin. Statistical analysis was by two way analysis of variance

\begin{tabular}{|c|c|c|c|c|c|c|c|c|c|c|}
\hline Treatment & Gilucose & Lactate & Pyrutate & $\begin{array}{l}\text { lactate: } \\
\text { pyruiate }\end{array}$ & $\begin{array}{l}\text { 3-Hydroxy- } \\
\text { butyrate }\end{array}$ & $\begin{array}{l}\text { Acerto- } \\
\text { acelate }\end{array}$ & $\begin{array}{l}\text { Total } \\
\text { ketone } \\
\text { bodies }\end{array}$ & $\begin{array}{l}3-0 H B \\
A C A C\end{array}$ & Glycerol & Alanine \\
\hline Porcine insulin & $\begin{array}{l}12 \cdot 8 \\
(1 \cdot 4)\end{array}$ & $\begin{array}{l}1.21 \\
(0.14)\end{array}$ & $\begin{array}{l}0.11 \\
(11 \cdot 01)\end{array}$ & $\begin{array}{l}10 \cdot 8 \\
(0 \cdot 4)\end{array}$ & $\begin{array}{c}0.22 \\
(0 \cdot 08)\end{array}$ & $\begin{array}{c}0 \cdot 14 \\
(0 \cdot(), 3)\end{array}$ & $\begin{array}{c}0.35 \\
(0 \cdot 11)\end{array}$ & $\begin{array}{c}1 \cdot 4 \\
(() \cdot 2)\end{array}$ & $\begin{array}{c}0.09 \\
(0 \cdot 01)\end{array}$ & $\begin{array}{c}0 \cdot 36 \\
(0 \cdot 03)\end{array}$ \\
\hline Human insulin & $\begin{array}{l}12 \cdot 6 \\
(1 \cdot 1)\end{array}$ & $\begin{array}{l}1 \cdot 43 \\
(0 \cdot 18)\end{array}$ & $\begin{array}{c}0 \cdot 12 \\
(0 \cdot(12)\end{array}$ & $\begin{array}{l}11 \cdot 8 \\
(0 \cdot 3)\end{array}$ & $\begin{array}{c}0.13 \\
(0.03)\end{array}$ & $\begin{array}{c}(0 \cdot 11 \\
(0 \cdot(02)\end{array}$ & $\begin{array}{c}0.24 \\
(0 \cdot(1) 4)\end{array}$ & $\begin{array}{c}1 \cdot 2 \\
(0 \cdot 1)\end{array}$ & $\begin{array}{c}0.08 \\
(0 \cdot 01)\end{array}$ & $\begin{array}{l}0 \cdot 35 \\
(0 \cdot(12)\end{array}$ \\
\hline F ratio & 0.24 & $7 \cdot 86$ & $3 \cdot 14$ & $36 \cdot 20$ & $11 \cdot(00$ & $12 \cdot 17$ & $13 \cdot 03$ & 3.82 & $10 \cdot 28$ & 0.85 \\
\hline p Value & NS & $<(1) \cdot(0) \mid$ & NS & $<0 .(0) 1$ & $<0.01$ & $<0 \cdot(x) 1$ & $<0 \cdot(0) 1$ & $<0.05$ & $<0.01$ & NS \\
\hline
\end{tabular}

$\mathrm{NS}=$ not significant: $3-() \mathrm{HB}: \mathrm{AcAc}=3$-hydroxybutyrate $:$ acetoacetate.

Conversion: SI to traditional units-(jlucose: $1 \mathrm{mmol} / \mathrm{l} \approx 18 \mathrm{mg} / 10() \mathrm{ml}$ : lactate $1 \mathrm{mmol} / \mathrm{l} \approx 9 \mathrm{mg} / 100 \mathrm{ml}$ : pyruvate $1 \mathrm{mmol} / \mathrm{l} \approx 8 \cdot 8 \mathrm{mg} / 1(0) \mathrm{ml}$; acetoacetate $1 \mathrm{mmol} / \mathrm{l} \approx 10.2 \mathrm{mg} / 100 \mathrm{ml}$ : glycerol $1 \mathrm{mmol} / \mathrm{l} \approx 9.2 \mathrm{mg} / 100 \mathrm{ml}$.

(Fig. 2), and the mean concentration was also greater after the evening insulin and meal. The higher concentrations persisted throughout the night. Over the 24 hours blood lactate concentration was significantly higher during treatment with human insulin (Table 2; F=7.86; $<<0 \cdot 01$ ).

Fasting blood pyruvate concentration was significantly lower during treatment with human insulin (Table 1). The diurnal pattern was similar to that observed for lactate, but differences between the two studies were small and not significant $(F=3 \cdot 14$; NS). The lactate:pyruvate ratio was significantly higher during treatment with human insulin both fasting (Table 1) and over 24 hours (Table 2; $\mathrm{F}=36 \cdot 2 ; \mathrm{p}<0 \cdot(001)$.

Total ketone bodies were not significantly different in fasting blood between studies (Table 1). The decrease after breakfast and morning insulin was more pronounced with human insulin (Fig. 3), and the mean concentrations over 24 hours were significantly lower (Table 2; F=13.03; $\mathrm{p}<0.001$ ). Blood glycerol concentration (Fig. 3) was also significantly lower during treatment with human insulin over the 24 hours (Table 2; $F=10 \cdot 28$; $\mathrm{p}<0 \cdot 01)$. Blood alanine concentration did not differ significantly between studies $(\mathrm{F}=0 \cdot 85$; NS).

Only one patient had a measurable $\mathrm{C}$ peptide concentration in all blood samples. In the remaining patients $C$ peptide was detected in a similar number of samples in each study (the maximum difference was five samples). With this within and between patient differences statistical analysis of the data is problematical. Student's paired $t$ test on $24 \mathrm{~h}$ mean C peptide or total C peptide (the sum of values over 24 hours) concentrations did not show a significant difference between studies. The group tended to have higher $C$ peptide concentrations during the second study, however, as is shown by linear regression of $\mathrm{C}$ peptide during human insulin versus
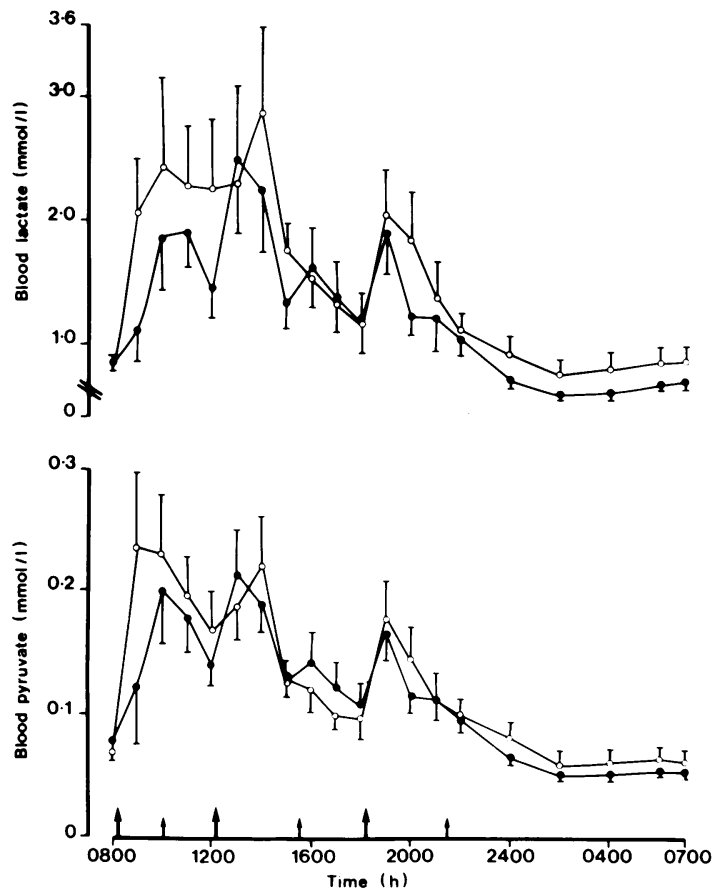

Fig. 2 Blood lactate and pyruvate concentrations (mean (SEM)) over 24 hours in eight adolescent diabetic patients during treatment with porcine (-) or human $(\mathrm{O}-\mathrm{O})$ insulin. The large arrows indicate meals and the small arrows snacks.

porcine insulin (for mean C peptide $\mathrm{y}=0 \cdot 86 \mathrm{x}+30 \cdot 8$, $\mathrm{r}=0.84 ; \mathrm{p}<0 \cdot 001$; for total $\mathrm{C}$ peptide $\mathrm{y}=0.80 \mathrm{x}+63$, $\mathrm{r}=0.83 ; \mathrm{p}<0 \cdot 001)$.

Serum growth hormone concentration was not significantly different between studies. Average $24 \mathrm{~h}$ mean concentration was $36.9 \mathrm{mu} / \mathrm{l}$ (range 15.7-51.0 $\mathrm{mu} / \mathrm{l}$ ) during treatment with porcine insulin and 33.9 

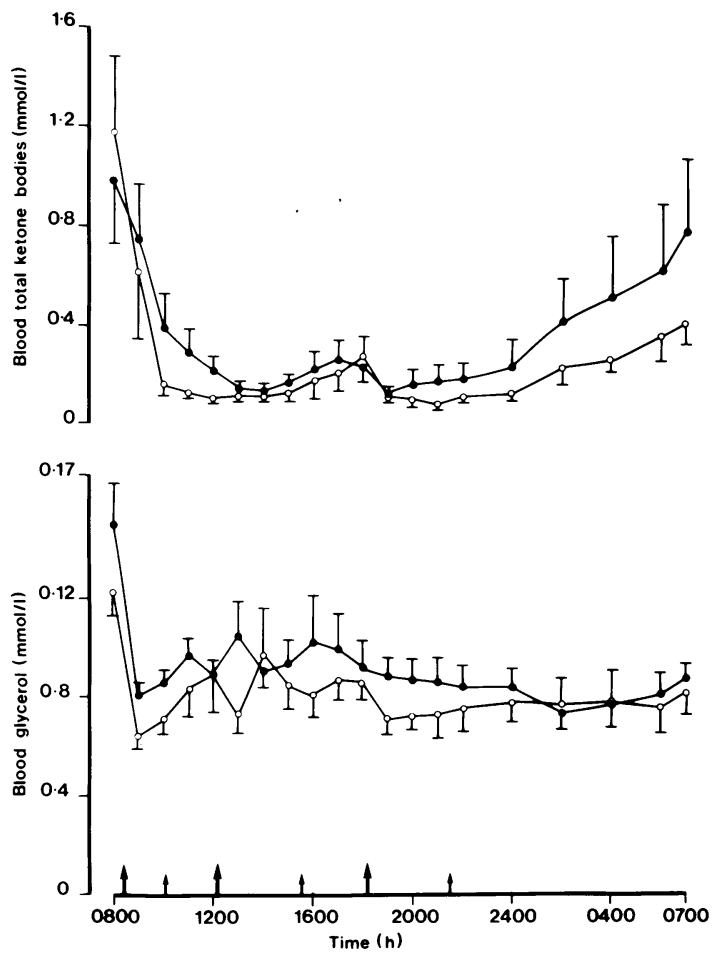

Fig. 3 Blood total ketone bodies and glycerol concentrations (mean (SEM)) over 24 hours in eight adolescent diabetic patients during treatment with porcine $(-)$ or human $\left(\mathrm{O}_{-}\right)$insulin. The large arrows indicate meals and the small arrows snacks.

$\mathrm{mu} / \mathrm{l}$ (range 18.6-54.6 mu/l) during treatment with human insulin.

\section{Discussion}

The production of human insulin is a major technological achievement, but it remains to be shown whether it has any advantage in clinical use over highly purified porcine insulin. In the present study we have examined the effect upon diabetic control of changing from treatment with porcine insulin to treatment with human insulin. During the two months of treatment with human insulin limited attempts were made to improve control through contact between the adolescent patients and the paediatrician, but this did not involve intensive attempts to change diet or exercise patterns.

There was a significant increase in insulin dose from a mean of $51 \mathrm{U} /$ day (range 26-84 U) on treatment with porcine insulin to $64 \mathrm{U} /$ day $(30-$
$104 \mathrm{U}$ ) on treatment with human insulin. Despite this increase no improvement was observed in total glycosylated haemoglobin, fasting blood glucose, or mean $24 \mathrm{~h}$ blood glucose concentrations. A change in the diurnal blood glucose pattern was found with concentrations lower after breakfast and higher during the night with treatment with human insulin. The amount of insulin given as intermediate acting insulin in the evening increased from mean (SD) 8 (6) units of porcine insulin to 15 (6) units of human insulin, and the findings are thus consistent with reports of a shorter duration of action of human intermediate acting insulins. ${ }^{\prime}$

The more pronounced fall in blood glucose concentrations after breakfast and morning human insulin led to greater rises in pyruvate and lactate concentrations at this time. Over 24 hours blood lactate concentration was significantly higher with human insulin consistent with the increased insulin dose enhancing peripheral lactate production.

Total ketone bodies were significantly lower during the human insulin study. Rates of hepatic ketone body production are determined largely by the rate of supply of non-esterified fatty acids to the liver and by alterations in the intrahepatic fate of fatty acids by hormones, particularly insulin. Decreased fatty acid supply to the liver during the second study is supported by the significant fall in glycerol that occurred, reflecting a decrease in lipolysis. This effect is likely to be due to an increased insulin dose rather than a different type of insulin. The diurnal pattern of total ketone bodies is abnormal, ${ }^{14}$ and in particular the pronounced rises that occur during the night with both treatments are clear indications of underinsulinisation. It is unclear whether the rise in total ketone bodies and presumably non-esterified fatty acids may exacerbate the rise in blood glucose concentration by impairing peripheral glucose uptake and oxidation as suggested by the glucose-fatty acid cycle. ${ }^{15}$

As we have previously reported, our ability to achieve good blood glucose control in adolescent diabetics is poor. ${ }^{16}$ Other groups report similar experience. Mann and Johnston improved control in diabetic children using $1.4 \mathrm{U} / \mathrm{kg} /$ day, but mean daily blood glucose (calculated from pre-meal values only) was still $10.6 \mathrm{mmol} / \mathrm{l}(191 \mathrm{mg} / 100 \mathrm{ml})$ and glycosylated haemoglobin concentration was $13.5 \%{ }^{17}$

In other studies of diabetic children the glycosylated haemoglobin concentration ranged from $11.5 \%$ to $14 \cdot 4 \% .{ }^{3}{ }^{4}$ We have encountered greatest difficulty overnight reflected in the grossly raised fasting blood glucose concentrations, and more strenuous attempts should be made to obtain fasting glucose concentrations nearer the normal range. 
In conclusion, changing adolescent insulin dependent diabetic patients from porcine to human (crb) insulin did not improve blood glucose control despite an increase in dose. Significantly lower total ketone bodies and glycerol concentrations were found while blood lactate concentration was higher. These metabolic changes were probably due to the increased insulin dose rather than any species difference in insulin.

MDH is an Eli Lilly Research Fellow. We are grateful to Sister Styles and to Dr B T Rudd for the growth hormone estimations. Statistical help was provided by Birmingham University Computer Centre. Financial support from Eli Lilly and the Bicentenary Advisory Board of the General Hospital, Birmingham, is gratefully acknowledged.

\section{References}

' Clarke RE, Kroeff EP, Hoffman JA, Frank BH. Chemical, physical and biological propertics of biosynthetic human insulin. Diabetes Care 1981;4:147-54.

2 Markussen J. Production of human insulin. In: Nattrass $M$, Santiago JV, cds. Recent advances in diabetes 1. Edinburgh: Churchill Livingstone, 1984:45-53.

${ }^{3}$ Greene SA, Smith MA, Cartwright B, Baum JD. Comparison of human versus porcine insulin in treatment of diabetes in children. Br Med J 1983;287:1578-9.

4 Mann NP, Johnston DJ, Reeves WG, Murphy MA. Human insulin and porcine insulin in the treatment of diabetic children: comparison of metabolic control and insulin antibody production. Br Med J 1983;287:1580-2.

${ }^{5}$ Keen H, Glynne A, Pickup JC, et al. Human insulin produced by recombinant DNA technology: safety and hypoglycaemic potency in healthy men. Lancet 1980;ii:398-401.

- Clark AJ, Adeniyi-Jones RO. Knight G, et al. Biosynthetic human insulin in the treatment of diabetes. A double-blind crossover trial in established diabetic patients. Lancet $1982 ;$ ii:354-7.

${ }^{7}$ Ludvigsson J, Heding L, Lieden G, Marner B, Lernmark A Plasmapheresis in the initial treatment of insulin-dependent diabetes mellitus in children. Br Med J 1983;286:176-8.

${ }^{8}$ Lloyd B, Burrin J, Smythe P, Alberti KGMM. Enzymatic fluorimetric continuous-flow assays for blood glucose, lactate, pyruvate, alanine, glycerol and 3-hydroxybutyrate. Clin Chem 1978;24:1724-9.

9 Price CP, Lloyd B, Alberti KGMM. A kinetic spectrophotometric assay for rapid determination of acetoacetate in blood. Clin Chem 1977:23:1893-7.

10 Hartog M, Gaafar MA, Meisser B, Fraser R. Immunoassay of serum growth hormone in acromegalic patients. $\mathrm{Br}$ Med J 1964;ii:1229-32.

"Heding LG. Radioimmunological determination of human C-peptide in serum. Diabetologia 1975;11:541-8.

12 Armitage P, Statistical methods in medical research. Oxford: Blackwell Scientific Publications, 1971:217-26.

${ }^{13}$ Foster KJ, Alberti KGMM, Hinks L, et al. Blood intermediary metabolite and insulin concentrations after an overnight fast: reference ranges for adults and interrelations. Clin Chem 1978;24:1568-72.

14 Wildenhoff KE. Diurnal variations in the concentrations of blood acetoacetate, 3-hydroxybutyrate and glucose in normal persons. Acta Med Scand 1972;191:303-6.

15 Randle PJ, Garland PB, Hales CN, Newsholme EA. The glucose fatty acid cycle. Its role in insulin sensitivity and the metabolic disturbances of diabetes mellitus. Lancet 1963;i: 785-9.

${ }^{16}$ Hocking MD, Rayner PHW, Nattrass M. Metabolic rhythms in adolescents with diabetes. Arch Dis Child 1986;61:124-9.

17 Mann NP, Johnston DJ. Improvement in metabolic control in diabetic adolescents by the use of increased insulin dose. Diabetes Care 1984;7:460-4.

Correspondence to Dr M Nattrass, Consultant Physician, General Hospital, Steelhouse Lane, Birmingham B4 6NH.

Received 3 January 1986 